\title{
Genetic Diversity Among Proso Millet (Panicum miliaceum) BIOTYPES ASSESSED BY AFLP TEChNIQUE ${ }^{1}$
}

\author{
Diversidade Genética entre Biótipos de Proso Millet (Panicum miliaceum) Revelada pela \\ Técnica de AFLP
}

\author{
KARAM, D. ${ }^{2}$, WESTRA, P. ${ }^{3}$, NISSEN, S.J. ${ }^{3}$, WARD, S.M. ${ }^{4}$ and FIGUEIREDO, J.E.F. ${ }^{5}$
}

\begin{abstract}
The Amplified Fragment Length Polymorphism (AFLP) technique was used to access genetic diversity between three domestic and nine wild proso millet biotypes from the United States and Canada. Eight primer combinations detected 39 polymorphic DNA fragments, with the genetic distance estimates among biotypes ranging from 0.02 to 0.04 . Colorado-Weld County black seeded and Wyoming-Platte County were the most distinct biotypes according to the dissimilarity level. A UPGMA cluster analysis revealed two distinct groups of proso millet without any geographic association. Six weed biotypes exhibiting some characters of cultivated plants were grouped together with domesticated biotypes of proso millet while the three typical wild phenotypes were clearly clustered into another group according to AFLP markers.
\end{abstract}

Key words: Proso millet, AFLP, taxonomic relationship, genetic diversity.

RESUMO - A técnica de AFLP (Amplified Fragment Length Polymorphism) foi empregada para acessar a diversidade genética entre três biótipos domesticados e nove biótipos selvagens de proso millet dos Estados Unidos e do Canadá. Oito combinações de primers detectaram 39 fragmentos polimórficos de DNA, e a estimativa da distância genética entre os biótipos variou de 0,02 a 0,04. Colorado-Weld County de sementes pretas e Wyoming-Platte County foram os biótipos mais distintos de acordo com o índice de dissimilaridade. A análise de cluster por UPGMA revelou dois grupos distintos de proso millet mas sem nenhuma relação geográfica. Seis biótipos selvagens que exibiam algumas características de plantas cultivadas foram agrupados juntamente com os biótipos domesticados de proso millet, enquanto os três fenótipos tipicamente selvagens formaram outro grupo distinto por marcadores AFLP.

Palavras-chave: Proso millet, AFLP, relação taxonômica, diversidade genética.

\section{INTRODUCTION}

Proso millet, the major cultivated grain crop in Europe since 2000, is currently produced in Eastern Europe, Russia, China, India, and North America (Anderson \& Martin, 1949; Grabouski, 1971; Baltensperger, 1996). It was first introduced to Canada in the $17^{\text {th }}$ Century. Wild-proso millet, the weed form of proso millet, has become one of the most aggressive grass weeds in North America over the past 25 years. (Bough \& Cavers, 1987). High infestation of wild-proso millet was first reported in Minnesota and Wisconsin in the early 1970s and since this period, proso millet weed has become a problem in different regions of the United States and Canada (Bough et al., 1986; Cavers \& Bough, 1985;

Recebido para publicação em 9.12.2003 e na forma revisada em 18.6.2004.

2 Ph.D., pesquisador da Empresa Brasileira de Pesquisa Agropecuária - Embrapa, Caixa Postal 151, 35701-970 Sete Lagoas-MG, Brazil, <karam@ cnpms.embrapa.br>. ${ }^{3}$ Ph.D., professor do Department of Bioagricultural Sciences and Pest Management, Colorado State University, Fort Collins, CO 80523; ${ }^{4}$ Ph.D., professor do Department of Soil Crop Science, Colorado State University. ${ }^{5}$ Ph.D., pesquisador da Empresa Brasileira de Pesquisa Agropecuária - Embrapa, <jeff@ cnpms.embrapa.br>. 
Doersch \& Cavers, 1979; Eberlein et al., 1990; Harvey, 1979; Strand et al., 1973; WSSA, 1992).

Even though it is considered to be a selfpollinated species with only about $10 \%$ of crosspollination, different types of proso millet have been reported (Colosi \& Shaal 1997). Although many studies of wild proso millet populations have been carried out, further work is necessary to understand the genetic basis of phenotypic variation among different ecotypes.

Molecular markers have been used to assess genetic diversity as well as to establish taxonomic and phylogenetic relationships in living organisms. Restriction fragment length polymorphism (RFLP) developed by Botstein et al. (1980) has been used as a tool for detecting polymorphism among and within weed and cultivated species (Guttieri et al., 1992; Krugman et al., 1997). Random amplified polymorphic DNA (RAPD) has also been used to detect polymorphism as well as to develop detailed genetic maps of weed species (Katzir et al., 1996; Vellekoop et al., 1996; Rowe et al. 1997). In proso millet, Colosi \& Shaal (1997) found 97 RAPD genotypes (69 wild proso millet, 26 crop and feral crop weed, and 2 hybrids between crop and wild types) among 398 individuals with DNA polymorphism suggesting hybridization between wild proso millet and crop biotypes in about $10 \%$ of the genotypes.

The AFLP (Amplified Fragment Length Polymorphism) technique for genomic DNA fingerprinting (Zabeau, 1992; Zabeau \& Vos 1993; Vos et al., 1995; Blears et al., 1998) has been used to evaluate levels of polymorphism, genetic mapping and cloning DNA sequences in a variety of cultivated species (Becker et al., 1995; Meksem et al., 1995; Cervera et al., 1996; Cho et al., 1996; Lin, et al., 1996; Mackill et al., 1996; Travis et al., 1996; VanToai et al., 1996a, b; Greef et al., 1997; Paul et al., 1997; Voorrips et al., 1997; Liscum \& Oeller, 1999). The AFLP fingerprinting was used for studying genetic structure between and within gene pools of wild bean (Phaseolus vulgaris) (Tohme et al., 1996) and genetic relationships among Kenyan tea (Camelia sinensis) (Paul et al., 1997) and Lactuca spp. (Hill et al., 1996). However, the use of AFLP for studying genotypic polymorphism in wild/ weed relatives of cultivated plants is still insufficient. The purpose of the present study was to evaluate the genetic diversity in wild and domesticated proso millet biotypes by using AFLP. Considerations will be raised about eco-physiological traits among biotypes.

\section{MATERIALS AND METHODS}

\section{Plant material}

Eight randomly selected plants for each of three domestic and nine wild biotypes of proso millet (Table 1) were grown in a chamber with $16 \mathrm{~h}$ photoperiod, $25-20{ }^{\circ} \mathrm{C}$ (day-night temperature), and $50 \%$ relative humidity for two weeks.

\section{DNA extraction}

Fresh leaves of each plant were ground with liquid nitrogen to obtain about $100 \mathrm{mg}$ of fine powder. Genomic DNA was extracted with Dneasy Plant Mini Kit (Qiagen Inc, Valencia, CA 91355). The procedure precipitates cell debris and salt using a QIA shredder spin column and the purified DNA is eluted from a Dneasy spin column. The DNA quality was checked in $1 \%$ agarose gels, its purity and concentration measured by a spectrophotometer $(260 / 280 \mathrm{~nm})$.

\section{AFLP procedure}

The AFLP procedure is property of KeyGene (Wageningen, The Netherlands) (Zabeau \& Vos 1993). The method used was based on AFLP Analysis System and AFLP Starter Primer protocol, provided by Life Technologies, with modifications. Restriction digestion of DNA was performed as described in GibcoBRL protocol. Briefly, $500 \mathrm{ng}$ of genomic DNA were digested for $2 \mathrm{~h}$ and $30 \mathrm{~min}$ at $37^{\circ} \mathrm{C}$, with 2.5 units of EcoR I and Mse I restriction enzymes using $2 \mu \mathrm{L}$ of a mix of EcoR I and Mse I, in buffer solution (10 mM Tris- $\mathrm{HCl}$ (pH 7.5), $50 \mathrm{mM} \mathrm{NaCl}$, $0.1 \mathrm{mM}$ EDTA, $1 \mathrm{mM}$ DTT, $0.1 \mathrm{mg} \mathrm{mL}^{-1} \mathrm{BSA}$, $50 \%$ (v/v) glycerol, $0.1 \%$ Triton $\left.^{\circledR} \mathrm{X}-100\right)$. The restriction enzymes were inactivated by heating reaction at $70{ }^{\circ} \mathrm{C}$ for $15 \mathrm{~min}$ and immediately placed on ice for $5 \mathrm{~min}$. Adaptor ligation reactions were performed with $24 \mu \mathrm{L}$ 
of adapter ligation solution (EcoR I and Mse I adapters, $0.4 \mathrm{mM}$ ATP, $10 \mathrm{mM}$ Tris- $\mathrm{HCl}(\mathrm{pH}$ 7.5), $10 \mathrm{mM} \mathrm{Mg}$-acetate, $50 \mathrm{mM} \mathrm{K}$-acetate), $1 \mu \mathrm{L}$

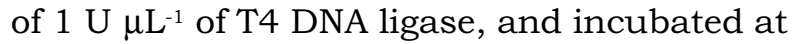
$20{ }^{\circ} \mathrm{C}$ for $2 \mathrm{~h}$. A pre-amplification reaction was made mixing $5 \mu \mathrm{L}$ of ligated DNA, $1 \mu \mathrm{L}$ of $1 \mathrm{U} \mu \mathrm{L}^{-1}$ Taq DNA polymerase, $5 \mu \mathrm{L}$ of $10 \mathrm{X}$ PCR buffer, and $40 \mu \mathrm{L}$ of pre-Amp primer mix, to a final volume of $51 \mu \mathrm{L}$. A 20 cycle $\left(94^{\circ} \mathrm{C}\right.$ for $30 \mathrm{~s}$, $52{ }^{\circ} \mathrm{C}$ for $60 \mathrm{~s}, 72^{\circ} \mathrm{C}$ for $\left.60 \mathrm{~s}\right)$ PCR was performed for pre-amplification of the DNA template. A dilution to $1: 4(\mathrm{v} / \mathrm{v})$ of the pre-amplified product was made using TE buffer. All reagents and solutions were obtained in the AFLP Core reagent kit from Life Technologies. Selective amplification was performed with modification from the original protocol from Life Technologies. EcoR I and Mse I primers (30 ng each) were mixed with $2 \mu \mathrm{L}$ of the diluted pre-amplified product, $2 \mu \mathrm{L}$ of $10 \times$ Taq buffer (200 mM Tris- $\mathrm{HCl}$ (pH 8.4), $15 \mathrm{mM} \mathrm{MgCl}_{2}$,

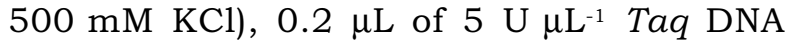
polymerase and brought to $20 \mu \mathrm{L}$ final volume with distilled water. The selective amplifications were performed using the following two/three (EcoR-TC/Mse-CAA; EcoRTG/Mse-CTC), and three/three pairs of primers (EcoR-AAG/Mse-CAA; EcoR-AGG/ Mse-CTT; Eco-AAG/Mse-CAG; EcoR-AGG/ Mse-CTAEcoR-AAC/Mse-CTT; EcoR-ACT/
Mse-CAA). The PCR program was: one cycle at $94^{\circ} \mathrm{C}$ for $30 \mathrm{~s} ; 65^{\circ} \mathrm{C}$ for $30 \mathrm{~s}$; and $72{ }^{\circ} \mathrm{C}$ for $60 \mathrm{~s}$; followed by a touch down phase of 13 cycles of $1{ }^{\circ} \mathrm{C}$ lower annealing temperature at each cycle. Afterwards, 23 cycles at $94^{\circ} \mathrm{C}$ for $30 \mathrm{~s}$; $56{ }^{\circ} \mathrm{C}$ for $30 \mathrm{~s}$; and $72{ }^{\circ} \mathrm{C}$ for $60 \mathrm{~s}$ were performed. The pre and selective amplifications were performed in a PTC- $100^{\mathrm{TM}}$ programmable Thermal Controller (MJ Research, Inc).

\section{Gel electrophoresis and silver stain}

After PCR, an equal volume of formamide dye (98\% formamide, $10 \mathrm{mM}$ EDTA, 0,005\% bromophenol blue, $0.005 \%$ xylene cyanol $\mathrm{FF}$ ) was added to each reaction tube. The samples were denatured by heating at $95{ }^{\circ} \mathrm{C}$ for $5 \mathrm{~min}$ and immediately placed on ice. Five micro liters of each sample were loaded on $5.3 \%$ polyacrylamide gel [20:1 polyacrylamide:bis; $7.5 \mathrm{M}$ Urea; $1 \mathrm{X}$ TBE buffer (54 g Tris; $55 \mathrm{~g}$ boric acid; $40 \mathrm{~mL} 0.25$ M EDTA $\mathrm{pH}$ 8.0)]. Electrophoresis was performed in a Sequi-Gen $0.04 \times 38 \times 50 \mathrm{~cm}$ apparatus (Bio-Rad Laboratories, Richmond, CA) in 1 X TBE buffer at constant power $(75 \mathrm{~W})$ for $2 \mathrm{~h}$ and $45 \mathrm{~min}$ at $50{ }^{\circ} \mathrm{C}$ with a PC 3000 Power Supply (Bio-Rad Laboratories, Richmond, CA).

Table 1 - Genetic similarity coefficients among proso millet biotypes estimated by Nei \& Li (1979) definition of similarity

\begin{tabular}{|c|c|c|c|c|c|c|c|c|c|c|c|c|c|c|}
\hline \multirow{2}{*}{$\begin{array}{l}\text { Accession } \\
\text { Number }\end{array}$} & \multirow{2}{*}{ Origin } & \multirow{2}{*}{$\begin{array}{l}\text { Seed } \\
\text { Color }\end{array}$} & \multicolumn{12}{|c|}{ Accession Number } \\
\hline & & & 1 & 2 & 3 & 4 & 5 & 6 & 7 & 8 & 9 & 10 & 11 & 12 \\
\hline 1 & Minnesota-Cambridge & olive & & & & & & & & & & & & \\
\hline 2 & Canada-Rosemount & black & 0.98 & & & & & & & & & & & \\
\hline 3 & Oregon-Grand Island & olive & 0.97 & 0.97 & & & & & & & & & & \\
\hline 4 & Canada-Huron County & black & 0.98 & 0.98 & 0.98 & & & & & & & & & \\
\hline 5 & Nebraska-Panhandle Center & $\tan$ & 0.97 & 0.96 & 0.97 & 0.96 & & & & & & & & \\
\hline 6 & Wyoming-Platte County & brown & 0.97 & 0.96 & 0.97 & 0.97 & 0.99 & & & & & & & \\
\hline 7 & Colorado-Weld County & black & 0.98 & 0.98 & 0.97 & 0.98 & 0.96 & 0.96 & & & & & & \\
\hline 8 & Colorado-Weld County & $\tan$ & 0.97 & 0.96 & 0.97 & 0.96 & 1.00 & 0.99 & 0.96 & & & & & \\
\hline 9 & South Dakota domesticated & brown & 0.98 & 0.98 & 0.97 & 0.98 & 0.97 & 0.96 & 0.99 & 0.96 & & & & \\
\hline 10 & Colorado domesticated & white & 0.98 & 0.99 & 0.97 & 0.98 & 0.97 & 0.96 & 0.99 & 0.96 & 0.99 & & & \\
\hline 11 & Colorado domesticated & orange & 0.98 & 1.00 & 0.97 & 0.98 & 0.96 & 0.96 & 0.99 & 0.96 & 0.99 & 0.99 & & \\
\hline 12 & Colorado-Larimer & white & 0.98 & 0.99 & 0.97 & 0.98 & 0.97 & 0.96 & 0.99 & 0.96 & 0.98 & 0.99 & 0.99 & \\
\hline
\end{tabular}


Gels were fixed with gentle agitation in $10 \%$ acetic acid followed by three 2 min water rinses. Silver staining was performed in a solution containing $2 \mathrm{~g}$ of silver nitrate and $3 \mathrm{~mL}$ of $37 \%$ formaldehyde in 2 liters of water, for $30 \mathrm{~min}$. Gels were then rinsed in water for $10 \mathrm{~s}$ and developed in a solution containing $60 \mathrm{~g}$ of sodium carbonate (Fisher Chemical); $3 \mathrm{~mL}$ formaldehyde; and $400 \mu \mathrm{L}$ of sodium thiosulfate (Fisher Chemical). Once bands were visible, the developing process was stopped by adding $10 \%$ glacial acetic acid solution.

\section{Data analysis}

The data were analyzed by the UPGMA (unweighted pair-group method with arithmetical averages) procedure of the NTSYS-PC software, version 2.02j (Exeter Software). Genetic distances were calculated following the equation:

$$
S_{i j}=2 a /(2 a+b+c)(\text { Nei \& Li 1979) }
$$

where $S_{i j}$ is the similarity index between two biotypes, $i$ and $j$; $a$ is the number of bands present in both $i$ and $j$ biotypes; $b$ is the number of bands present only in the $i$ biotype and $c$ is the number of bands present only in the $j$ biotype. Conversion to genetic distance $\left(G d_{i j}\right)$ was made by:

$$
G d_{i j}=1-S_{i j}
$$

Genetic similarities were measured by using the equation:

$$
G s_{i j}=C_{i j} / N_{i j}
$$

where $G s_{i j}$ is the measurement of the genetic similarity between biotypes $i$ and $j, C_{i j}$ is the number of bands present in $i$ and $j$, and $N_{i j}$ is the total number of bands scored (Hill et al., 1996).

\section{RESULTS AND DISCUSSION}

In the present study, a high resolution silver stained polyacrylamide gel without radioactive isotopes showed to be efficient to visualize PCR amplified fragments of proso millet genomic DNA by AFLP technique (data not shown). Vos et al. (1995) reported that 50 to 100 fragments of DNA are the typical AFLP restricted amplified fragments detected by radioisotopes on electrophoresis in polyacrylamide gel. Our results, averaging 56 amplified fragments per gel, showed that silver stained polyacrylamide gel retained the resolution power of radiolabeled primers and can be used to assign genetic variability in proso millet. Silver-staining method is preferable to standard radioactive method because it eliminates the need of working with radioactivity (Chalhoub et al., 1997).

Eight combinations of AFLP primers produced at least 450 fragments, at times difficult to read; of these; 339 were clearly separated with 39 polymorphic DNA fragments being detected (Table 1). The combination of primers with two selective nucleotides and three selective nucleotides amplified more DNA fragments than the combination of three and three selective nucleotides (data not shown). Those bands were, however, difficult to read.

Blears et al. (1998), in a review of the AFLP procedure and its application, states that small genomes $\left(10^{6}-10^{7}\right.$ base pairs) need one to two selective nucleotides on the 3 ' end of each primer to detect polymorphism while more complex genomes $\left(10^{8}-10^{10}\right.$ base pair) need additional selective nucleotides. In proso millet with a small genome $\left(10^{6}\right.$ base pairs), pairs of primers with two selective nucleotides were unable to reveal DNA polymorphism among biotypes (data not shown) while primer combinations, Mse-CTT/EcoR-AAC and Mse-CAA/EcoR-ACT were effective producing, on average, eight polymorphic fragments (Table 1).

To gain insight about the genetic relationships among proso millet biotypes, a matrix of the presence or absence of bands was analyzed by two methods. Genetic distance was determined according to Nei \& Li's (1979) and genetic similarity according to Tohme et al. (1996). Table 1 shows the genetic similarity calculated among proso millet biotypes. The results showed that the genetic distance ranged from 0.02 to 0.04 . The greatest distance was observed between Colorado-Weld County black seeded biotypes and Wyoming-Platte County brown seeded biotypes. The closest related biotypes were the two wild-tan seeded biotypes (Nebraska-Panhandle Center and Colorado-Weld County). 
Analysis conducted by M'Ribu \& Hilu (1994) through RAPD and UPGMA association based on Dice's algorithm of similarity, (1945) grouped proso millet according to their geographic origin. In the present study using the same unweighted pair group method but based on NEI 72 (Nei, 1972), the biotypes did not group by geographic distribution. It should be pointed out that the geographic location observed in our study was more limited than the scale verified in M'Ribu \& Hilu (1994). To verify and contrast our results with M'Ribu \& Hilu (1994), a cluster analysis was performed based on the same DICE algorithms. Coefficients estimated from DICE algorithms ranged from 0.96 to 1.0 while M'Ribu \& Hilu (1994) estimated coefficients varying from 0.60 and 1.0. The UPGMA cluster analysis based on NEI 72 algorithm clearly identified two distinct clusters in proso millet biotypes (Table 2): a group formed only by weed biotypes and a group composed by domesticated and weed biotypes displaying domesticated characters. Studies carried out by Karam (2000) showed that some traits in weed biotypes of proso millet were expected for domesticated varieties while early biomass accumulation and early leaf area development showed a correlation between the expected trait and eco-physiological parameters for domesticated and weed biotypes in the same group of the twelve proso millet analyzed in the present study.

Studies focusing on eco-physiological traits (mean of dry shoot weight, leaf area, absolute growth rate, plant height, and dry weight partitioning) showed that seed weight and seed coat percentage were not significantly different between Canada-Rosemount and Colorado tan seeded biotypes (Karam, 2000). However, when comparing the competitive ability of both biotypes, differences were detected with Canada-Rosemount biotype being more aggressive than Colorado biotype. The author also showed differences in nutrient accumulation between Canada-Rosemount and Colorado tan seeded biotypes. It was stated that the differences observed in growth and competitive ability might be related to genetic differences between the biotypes (Karam, 2000). Even so, $9 \%$ of polymorphic DNA between Canada-Rosemount and Colorado tan seeded biotypes (Table 2) were found in this study. Based on AFLP polymorphic DNA fragment analysis and the genetic distance estimates, we find Canada-Rosemount to be more closely related to domestic biotypes than tan-seeded and Ontario-Canada black-seeded biotypes.

Table 2 - Ratio of polymorphic DNA fragments detected by AFLP procedure on domestic and wild proso millet biotypes estimated by Nei \& Li (1979) definition of similarity

\begin{tabular}{|c|c|c|c|c|c|c|c|c|c|c|c|c|c|c|}
\hline \multirow{2}{*}{$\begin{array}{l}\text { Accession } \\
\text { Number }\end{array}$} & \multirow{2}{*}{ Origin } & \multirow{2}{*}{$\begin{array}{l}\text { Seed } \\
\text { Color }\end{array}$} & \multicolumn{12}{|c|}{ Accession Number } \\
\hline & & & 1 & 2 & 3 & 4 & 5 & 6 & 7 & 8 & 9 & 10 & 11 & 12 \\
\hline 1 & Minnesota-Cambridge & olive & & & & & & & & & & & & \\
\hline 2 & Canada-Rosemount & black & 0.04 & & & & & & & & & & & \\
\hline 3 & Oregon-Grand Island & olive & 0.06 & 0.06 & & & & & & & & & & \\
\hline 4 & Canada-Huron County & black & 0.05 & 0.04 & 0.05 & & & & & & & & & \\
\hline 5 & Nebraska-Panhandle Center & $\tan$ & 0.07 & 0.09 & 0.07 & 0.08 & & & & & & & & \\
\hline 6 & Wyoming-Platte County & brown & 0.06 & 0.08 & 0.06 & 0.07 & 0.02 & & & & & & & \\
\hline 7 & Colorado-Weld County & black & 0.05 & 0.03 & 0.06 & 0.05 & 0.07 & 0.09 & & & & & & \\
\hline 8 & Colorado-Weld County & $\tan$ & 0.07 & 0.09 & 0.06 & 0.08 & 0.00 & 0.02 & 0.08 & & & & & \\
\hline 9 & South Dakota domesticated & brown & 0.05 & 0.04 & 0.07 & 0.05 & 0.07 & 0.08 & 0.02 & 0.08 & & & & \\
\hline 10 & Colorado domesticated & white & 0.03 & 0.03 & 0.05 & 0.05 & 0.07 & 0.08 & 0.02 & 0.08 & 0.02 & & & \\
\hline 11 & Colorado domesticated & orange & 0.03 & 0.01 & 0.06 & 0.04 & 0.08 & 0.08 & 0.01 & 0.08 & 0.03 & 0.02 & & \\
\hline 12 & Colorado-Larimer & white & 0.03 & 0.02 & 0.06 & 0.05 & 0.07 & 0.08 & 0.02 & 0.08 & 0.04 & 0.02 & 0.02 & \\
\hline
\end{tabular}


In a study carried out by Karam (2000), twelve proso millet biotypes were arranged into three groups according to radicle length parameter. Two groups were formed by plants clearly displaying cultivated and weed plant characters (radicle length average of $4.46 \mathrm{~mm}$ and $0.76 \mathrm{~mm}$, respectively), and a third group was composed by plants that although being classified as weed biotypes (MinnesotaCambridge, Oregon-Grand Island wild Olive, Ontario Canada Huron County wild black, Canada Rosemount wild black and ColoradoWeld County wild black), showed intermediate values for radicle length average $(2.03 \mathrm{~mm})$ between cultivated and weed proso millet. In the present study, the twelve proso millet populations were arranged into two clusters by AFLP markers. According to Karam (2000), proso millet biotypes of the third intermediate group also showed some cultivated plant characters, such as non-dormant seeds, which are features characteristic of domesticated crop varieties. Previous studies with ecophysiological traits concluded that MinnesotaCambridge showed less weed characteristics than other wild biotypes and originated through hybridization events between wild and domestic proso millet biotypes (Striegel \& Boldt, 1981; Eberlein et al., 1990; Westra \& Callan, 1990), through analysis performed by RAPD (Colosi \& Schaal, 1997) showed that Minnesota-Cambridge biotype was genetically intermediate between wild and domesticated proso millet. In the present study the percentage of AFLP polymorphic bands detected between Minnesota-Cambridge and the other wild biotypes was $6.4 \%$, while the percentage within the wild group was $3.9 \%$. In this case, it should be pointed out that gene flow between cultivated and weed forms of proso millet accounts both for intermediate morpho-physiological types of proso millet encountered by Karam (2000) and clustering weed types within cultivated proso millet according to AFLP genetic markers, in the present study.

Even though it is considered an autogamous species, studies by Popov (1947) reported at least $10 \%$ of cross-pollination occurring between proso millet biotypes. Gene flow between weed and cultivated proso millet biotypes may be important for maintaining genetic variability in this species and could partially explain the aggressiveness and success of proso millet weed in colonizing a wide range of environments in North America. Further studies are necessary to understand the relative contribution of gene flow among wild and cultivated biotypes of proso millet for a successful proso millet weed cultivation and weed management. It should be stated that since proso millet is a self-pollinated species, this study was carried out using eight plants developed from seeds selected from bulk population of each biotype. We suspect that the variations observed in this study are more related to the variations that may occur within a population than to the variations across populations.

\section{ACKNOWLEDGEMENTS}

The first author wishes to thank Brazilian Agriculture Research Corporation - Embrapa for the financial support.

\section{LITERATURE CITED}

ANDERSON, E.; MARTIN, J. D. World production and consumption of millet and sorghum. Econ. Bot., n. 3, p. 265-288, 1949.

BALTENSPERGER, D. D. Foxtail and proso millet. In: JANICK, J. (Ed.) Progress in new crops. Alexandria, VA: ASHS Press, 1996. p. 182-190.

BECKER, J. et al. Combined mapping of AFLP and RFLP markers in barley. Mol. Gen. Genet., v. 249, p. 65-73, 1995.

BLEARS, M. J. et al. Amplified fragment length polymorphism (AFLP): a review of the procedure and its application. J. Ind. Microbiol. Biotec., v. 21, p. 99-114, 1998.

BOTSTEIN, D. et al. Construction of a genetic linkage map in man using restriction fragment length polymorphisms.

Am. J. Human Gen., v. 32, p. 314-331, 1980.

BOUGH, M. J.; CAVERS, P. B. Proso millet. Ontario: Ministry of agriculture and Food. Factsheet, n. 87, p. 254, 1987.

BOUGH, M.; COLOSI, J. C.; CAVERS, P. B. The major weed biotypes of proso millet (Panicum miliaceum) in Canada. Can. J. Bot., v. 64, p. 1188-1198, 1986. 
CAVERS, P. B.; BOUGH, M. A. Proso millet (Panicum miliaceum L.): a crop and a weed. In: WHITE, J. (Ed.) Studies on plant demography: a festschrift for John L. Harper. Orlando: Academic Press, 1985. p. 143-155.

CERVERA, M. T. et al. Amplification of AFLP based molecular markers to breeding of Populus spp. Plant Growth Regul., v. 20, p. 47-52, 1996.

CHALHOUB, B. A. et al. Silver staining and recovery of $\mathrm{AFLP}^{\mathrm{TM}}$ amplification products on large denaturing polyacrylamide gels. Biotechniques, v. 22, p. 216-220, 1997.

CHO, Y. C. et al. Cloning and mapping of variety-specific rice genomic DNA sequences: amplified fragment length polymorphism (AFLP) from silver-stained polyacrylamide gels. Genome, n. 39, p. 373-378, 1996.

COLOSI, J. C.; SCHAAL, B. A. Wild Proso Millet (Panicum miliaceum) isgenetically variable and distinct from crop varieties of proso millet. Weed Sci., v. 45, p. 509-518, 1997.

DICE, L. R. Measures of the amount of ecological association between species. Ecology, v. 26, p. 295-302, 1945.

DOERSCH, R. E.; CAVERS, R. G. Wild proso millet in corn. Proc. North Cent. Weed Control Conf., n. 34, p. 58-59, 1979.

EBERLEIN, C. V. et al. Growth and development of wild proso millet (Panicum miliaceum) biotypes. Weed Technol., v. 4, p. 415-419, 1990.

GRABOUSKI, P. H. Selective control of weeds in proso millet with herbicides. Weed Sci., v. 19, p. 207-209, 1971.

GREEF, J. M. et al. Genetic diversity of European Miscanthus species revealed by AFLP fingerprinting. Genetic Resources Crop Evol., v. 44, p. 185-195, 1997.

GUTTIERI, M. J. et al. DNA sequence variation in domain A of the acetolactate synthase genes of herbicide-resistant and susceptible weed biotypes. Weed Sci., v. 40, p. 670-676, 1992.

HARVEY, R.G. Wild proso millet: serious new weed threat. Crops Soil Manag., v. 31, p. 10-13, 1979.

HILL, M. et al. PCR-based fingerprinting using AFLPs as a tool for studying genetic relationships in Lactuca spp. Theor. Appl. Gen., v. 93, p. 1202-1210, 1996.

KARAM, D. Wild proso millet (Panicum miliaceum L.): Growth analysis, competitive ability and genetic variation. 2000. $358 \mathrm{f}$. Thesis (Ph.D.) - Colorado State University, 2000.

KATZIR, N. et al. Use of random amplified polymorphic DNA (RAPD) markers in the study of the parasitic weed Orobanche. Theor Appl. Gen., v. 93, p. 367-372, 1996.
KRUGMAN, T. et al. Comparative RFLP mapping of the chlorotoluron resistance gene (Su1) in cultivated wheat (Triticum aestivum) and wild wheat (Triticum dicoccoides). Theor. Appl. Gen., v. 94, p. 46-51, 1997.

LIN, J. et al. Identification of molecular markers in soybean comparing RFLP, RAPD, and AFLP DNA mapping techniques. Plant Mol. Biol. Rep., v. 14, p. 156-169, 1996.

LISCUM, M.; OELLER, P. AFLP: not only for fingerprinting, but for positional cloning. Stanford: Carnegie Institution of Washington, 1999. Disponível em: <http:// carnegiedpb. stanford.edu/methods/aflp.html>. Acesso em: 15 out 2003 .

MACKILL, D. J. et al. Level of polymorphism and genetic mapping of AFLP markers in rice. Genome, v. 39, p. 969977, 1996.

M'RIBU, H. K.; HILU, K. W. Detection of interspecific and intraspecific variation in Panicum millets through random amplified polymorphic DNA. Theor. Appl. Genet. v. 88, p. 412-416, 1994.

NEI, M. Genetic distance between populations. Am. Nat., v. 106, p. 283-292, 1972.

NEI, M.; LI, W. H. Mathematical model for studying genetic variation in terms of restriction endonucleases. Proc. Nat. Acad. Sci., USA, v. 76, p. 5269-5273, 1979.

PAUL, S. et al. Diversity and genetic differentiation among populations of Indian and Kenyan tea (Camellia sinensis (L.) O. Kuntze) revealed by AFLP markers. Theor. Appl. Genet., v. 94, p. 255-263, 1997.

POPOV, G. I. The importance of diversity in millet. Plant Breed. Abstr., v. 17, p. 453, 1947.

ROWE, M. L. et al. Genetic variation in North American leafy spurge (Euphorbia esula) determined by DNA markers. Weed Sci., v. 45, p. 446-454, 1997.

STRAND, O. E.; BEHRENS, R.; MILLER, G. R. Wild proso millet, Panicum miliaceum L., a new weed problem in Minnesota. Proc. North Central Weed Control Conf., p. 51-52, 1973.

STRIEGEL, W. L.; BOLDT, P. F. Germination and emergence characteristics of wild proso millet. Proc. North Central Weed Control Conf., p. 22, 1981.

TOHME, J. et al. AFLP Analysis of Gene Pools of a Wild Bean Core Collection. Crop Sci., v. 36, p. 1375-1384, 1996.

TRAVIS, S. E.; MASCHINSKI, J. `; KEIN, P. An analysis of genetic variation in Astragalus cremnophylax var. cremnophylax, a critically endangered plant, using AFLP markers. Mol. Ecol., v. 5, p. 735-745, 1996. 
VANTOAI, T. T.; PENG, J. Q.; MARTIN, S. Using AFLP markers to determine the contribution of parental genomes during recurrent selection. Soybean Genetic Newsletter, v. 23 , p. $214-216,1996$ a.

VANTOAI, T. T.; PENG, J. Q.; MARTIN, S. Optimization of Silver-Staining AFLP Technique for Soybean. Soybean Genetic Newsl., v. 23, p. 206-209, 1996b.

VELLEKOOP, P. et al. Can the spread of agriculture in Europe be followed by tracing the spread of the weed Silene latifolia. A RAPD study. Theor. Appl. Gen., v. 92, p. 10851090, 1996.

VOORRIPS, R. E.; JONGERIUS, M. C.; KANNE, H. J. Mapping of two genes for resistance to clubroot (Plasmodiophora brassicae) in a population of doubled haploid lines of Brassica oleracea by means of RFLP and AFLP markers. Theor. Appl. Gen., v. 94, p. 75-82, 1997.
VOS, P. et al. AFLP: a new technique for DNA fingerprinting. Nucleic Acids Res., v. 23, p. 4407-4414, 1995.

ZABEAU, M. European Patent Application, 1992. (Publication no. EP 0534858)

ZABEAU, M.; VOS, P. European Patent Application. 1993. (Publication no. EP 0534858)

WESTRA, P.; CALLAN, M. Morphological and reproductive characteristics of fifteen wild proso millet (Panicum miliaceum) accessions from the United States and Canada. Res. Prog. Report West. Soc. Weed Sci., p. 405407, 1990.

WSSA. Crop losses due to weeds in the United States. Weed Sci. Soc. Am., p. 75-147, 1992. 